\title{
(- OPEN ACCESS \\ Disseminated cryptococcal infection in a patient who had kidney transplant: discrepancy between clinical symptoms and microbiological findings
}

\author{
Suzan Dahdal, ${ }^{1}$ Robert Kalicki, ${ }^{1}$ Niklaus Von Steiger, ${ }^{2}$ Parham Sendi ${ }^{2,3}$
}

'Department of Nephrology, Hypertension and Clinical Pharmacology, Inselspital, Bern University Hospital, University of Bern, Bern, Switzerland ${ }^{2}$ Institute of Infectious Diseases, University of Bern, Bern, Switzerland

${ }^{3}$ Department of Infectious Diseases, Inselspital, Bern University Hospital, University of Bern, Bern, Switzerland

Correspondence to Dr Suzan Dahdal, suzandahdal@gmail.com

Accepted 9 July 2017

\section{CrossMark}

\section{To cite: Dahdal $S$, Kalicki $R$,} Von Steiger N, et al. BMJ Case Rep Published Online First: [please include Day Month Year]. doi:10.1136/ bcr-2017-219234

\section{SUMMARY}

A 29-year-old man complained of a 2-day history of frontal headache and new-onset fever but no other symptoms. Two months prior to admission, he underwent his third kidney transplantation. Clinical and laboratory examinations were unremarkable. Brain MRI showed a meningeal irritation consistent with viral meningitis. A diagnosis of cryptococcal meningitis and fungaemia was made after detection of a remarkably high and visible load of Cryptococcus neoformans in the cerebrospinal fluid.

\section{BACKGROUND}

Invasive cryptococcosis is the third most common invasive fungal infection among organ transplant recipients. ${ }^{1}$ The most frequently encountered clinical manifestation is the cryptococcal meningoencephalitis (CM) which may be easily misdiagnosed because of varying clinical presentations. Here, we report a case of $\mathrm{CM}$ and fungaemia in a patient who had kidney transplant, which illustrates the difficulty of estimating the real extent of the disease when only clinical features are considered.

\section{CASE PRESENTATION}

A 29-year-old male patient with congenital cystinosis and who had kidney transplant was admitted to hospital because of headache and a single episode of fever $\left(39.2^{\circ} \mathrm{C}\right)$. Two months prior to admission, he underwent his third kidney transplantation. The previous kidney transplantations were performed at the age of 12 and 21 years, respectively. Both renal grafts were lost due to antibody-mediated rejection. Induction immunosuppressive therapy consisted of a total dose of $40 \mathrm{mg}$ basiliximab $(20 \mathrm{mg}$ on day 0 and $20 \mathrm{mg}$ on day 4) and three boluses of $500 \mathrm{mg}$ prednisolone intravenously. Prednisolone was then slowly tapered off to a maintenance dose of $5 \mathrm{mg} /$ day. Maintenance therapy consisted of tacrolimus (target trough level of $10 \mathrm{ng} / \mathrm{mL}$ ) and $2 \mathrm{~g} /$ day mycophenolate mofetil. Postoperative renal graft function was excellent, with the serum creatinine level stabilised at $90 \mu \mathrm{mol} / \mathrm{L}$.

\section{INVESTIGATIONS}

On admission, the patient complained of no other symptoms than headache. Physical examination revealed no pathological findings and a body temperature of $36.4^{\circ} \mathrm{C}$. Blood test results showed neither leucocytosis nor an elevated $\mathrm{C}$ reactive protein level. Acute sinusitis was suspected but a CT scan of the paranasal sinuses was unremarkable. On day 2, the headache persisted and he was not responding to analgesics. The findings in the brain MRI were indicative of a meningeal irritation (figure 1). A lumbar puncture was performed. The opening pressure was normal $\left(10 \mathrm{~cm} \mathrm{H}_{2} \mathrm{O}\right)$, but the cell count in the cerebral spinal fluid (CSF) of $28 \times 10^{6} / \mathrm{L}(65 \%$ mononuclear $)$ and the lactate $(2.9 \mathrm{mmol} / \mathrm{L})$, glucose $(5.3 \mathrm{mmol} / \mathrm{L})$ and albumin $(564 \mathrm{mg} / \mathrm{L})$ levels were slightly elevated. Viral PCR test results and bacterial culture from the CSF remained negative. However, India ink staining revealed a surprisingly high quantity of encapsulated yeast forms in the CSF (figure 2A). In addition, cryptococcal antigen tests in both CSF and blood were positive. Cryptococcus neoformans grew in cultures from CSF and all blood cultures obtained (figure 2B), leading to a diagnosis of cryptococcal meningitis and fungaemia.

\section{TREATMENT}

After the patient received induction therapy with liposomal amphotericin B $200 \mathrm{mg}$ daily intravenously (cumulative doses $2800 \mathrm{mg}$ ) and flucytosine 2.5 gr q8h intravenously for 2 weeks, a subsequent lumbar puncture detected no fungal growth. Consolidation therapy followed, with fluconazole $200 \mathrm{mg}$ daily orally for 34 weeks.

\section{OUTCOME AND FOLLOW-UP}

At the last follow-up (3 years after the episode), the patient was in good health.

\section{DISCUSSION}

Infection with C. neoformans in solid organ transplant recipients usually occurs in the late post-transplantation period (>6 months after transplantation). ${ }^{1-3}$ Susceptibility to opportunistic infections in solid organ transplant recipients is to a large extent dependent on the net state of immunosuppression. ${ }^{4}$ Glucocorticoids seem to facilitate infection with C. neoformans by decreasing cell-mediated immunity. ${ }^{5}$ An induction therapy with basiliximab is associated with a low incidence $(0.4 \%)$ of $\mathrm{CM}^{7}{ }^{7}$ In contrast, patients treated with tacrolimus are less prone to cerebral involvement, probably because of its antifungal effect and ability to cross the bloodbrain-barrier. $^{2}$ 

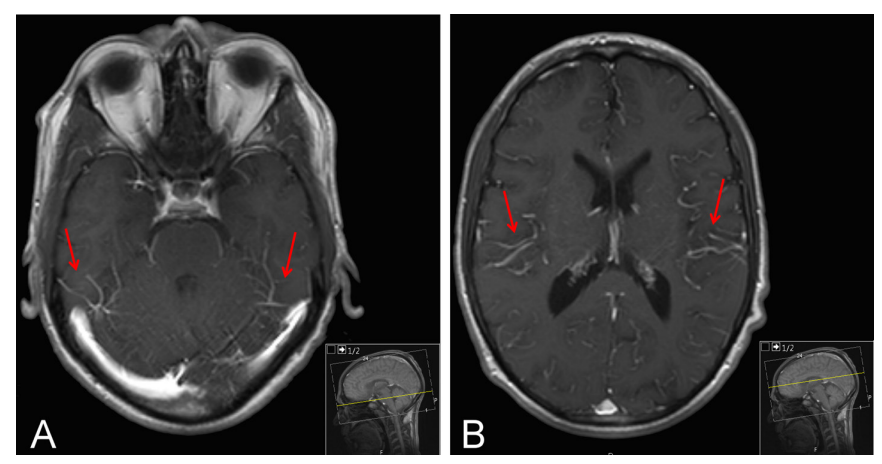

Figure 1 T1-weighted MR brain images on two different levels ( $\mathrm{A}$ and B): enhancement of leptomeningeal vessels (red arrows), a common sign of meningeal irritation.

Both animal model ${ }^{8}$ and human data ${ }^{12}$ point out the additive immunosuppressive effect of uraemia facilitating C. neoformans infections. Our patient had, however, a normal renal function and the infection occurred early, only 2 months after transplantation. In this early period, glucocorticoids were given at a relatively high dose. Furthermore, he had a long cumulative exposure to immunosuppressive agents since his first kidney transplant, which explained the high net state of immunosuppression. ${ }^{4}$ Cases of donor-derived cryptococcal disease have been reported. ${ }^{9}$ Here, the donor had no history of diseases or infection. In addition, the recipient of the other kidney had no cryptococcal infection.

Although a high fungal load suggests more apparent illness, our patient was in a good clinical condition and displayed only headache and fever. As photophobia is commonly seen in congenital cystinosis, it could not be considered as a feature of CM in our patient. Other symptoms such as altered mental status were also absent. In addition, the CSF opening pressure was normal even though an elevated opening pressure is typically found in CM (eg, mean of $33 \mathrm{~cm} \mathrm{H}_{2} \mathrm{O}$ in ref. 3). CM typically occurs in immunocompromised hosts, such as solid organ transplant recipients. It is an important reminder of a clinical lesson that these patients often present mild and atypical symptoms. In this case, the
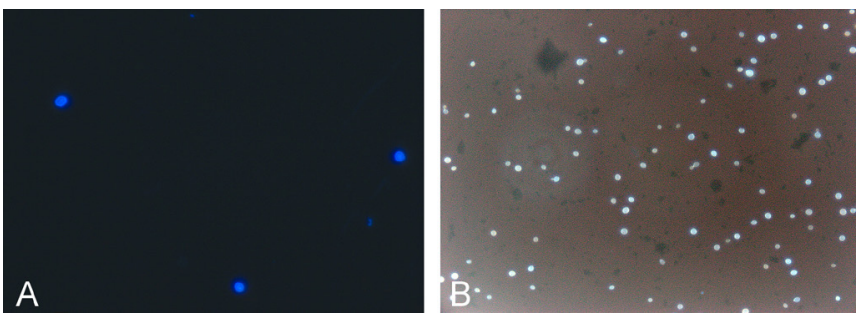

Figure 2 (A) India ink staining of cerebrospinal fluid after lumbar puncture. (B) Calcofluor staining of blood cultures showing yeasts with prominent capsules. radiological findings and the striking microscopic images of the CSF sample were the key to the diagnosis.

This case was presented at the 80th annual meeting of the Swiss Society of Internal Medicine (Poster P328). ${ }^{10}$

\section{Learning points}

- Invasive fungal infection with Cryptococcus neoformans is a severe opportunistic infection with a high mortality rate in solid transplant recipients.

- Immunosuppression remains the only and most serious risk factor for infection with $C$ neoformans.

- A high index of suspicion for CM should be applied for solid organ transplant patients who exhibit headache or fever, even with minor symptoms and normal laboratory results.

Contributors SD: Conception of the case report, data analysis and interpretation, drafting the article, final approval of the version to be published. RK: Data analysis and interpretation, critical revision of the article, final approval of the version to be published. NVS: Data analysis and interpretation, final approval of the version to be published. PS: Data analysis and interpretation, critical revision of the article, final approval of the version to be published.

Competing interests None declared.

Patient consent Obtained.

Provenance and peer review Not commissioned; externally peer reviewed.

Open Access This is an Open Access article distributed in accordance with the Creative Commons Attribution Non Commercial (CC BY-NC 4.0) license, which permits others to distribute, remix, adapt, build upon this work non-commercially, and license their derivative works on different terms, provided the original work is properly cited and the use is non-commercial. See: http://creativecommons.org/ licenses/by-nc/4.0/

(c) BMJ Publishing Group Ltd (unless otherwise stated in the text of the article) 2017. All rights reserved. No commercial use is permitted unless otherwise expressly granted.

\section{REFERENCES}

1 Pappas PG, Alexander BD, Andes DR, et al. Invasive fungal infections among organ transplant recipients: results of the Transplant-Associated Infection Surveillance Network (TRANSNET). Clin Infect Dis 2010;50:1101-11.

2 Singh N, Alexander BD, Lortholary 0, et al. Cryptococcus neoformans in organ transplant recipients: impact of calcineurin-inhibitor agents on mortality. J Infect Dis 2007; 195:756-64.

3 Husain S, Wagener MM, Singh N. Cryptococcus neoformans infection in organ transplant recipients: variables influencing clinical characteristics and outcome. Emerg Infect Dis 2001;7:375-81.

4 Fishman JA. Infection in solid-organ transplant recipients. N Engl J Med 2007;357:2601-14.

5 Hajjeh RA, Conn LA, Stephens DS, et al. Cryptococcosis: population-based multistate active surveillance and risk factors in human immunodeficiency virus-infected persons. cryptococcal active Surveillance Group. J Infect Dis 1999;179:449-54.

6 Murphy JF, McDonald FD, Dawson M, et al. Factors affecting the frequency infection in renal transplant recipients. Arch Intern Med 1976;136:670-7.

7 Atlani M, Sharma RK, Gupta A. Basiliximab induction in renal transplantation: longterm outcome. Saudi J Kidney Dis Transp/ 2013;24:473-9.

8 Fromtling RA, Fromtling AM, Staib F, et al. Effect of uremia on lymphocyte transformation and chemiluminescence by spleen cells of normal and cryptococcus neoformans-infected mice. Infect Immun 1981;32:1073-8.

9 MacEwen CR, Ryan A, Winearls CG. Donor transmission of cryptococcus neoformans presenting late after renal transplantation. Clin Kidney J 2013;6:224-7.

10 Dahdal SV D, Kalicki R, Sendi P. Paucisymptomatic cryptococcal meningitis andfungaemia in a kidney transplant patient. Schweiz Med Forum 2012;12(Supp 58):42S 
Copyright 2017 BMJ Publishing Group. All rights reserved. For permission to reuse any of this content visit http://group.bmj.com/group/rights-licensing/permissions.

BMJ Case Report Fellows may re-use this article for personal use and teaching without any further permission.

Become a Fellow of BMJ Case Reports today and you can:

- Submit as many cases as you like

- Enjoy fast sympathetic peer review and rapid publication of accepted articles

Access all the published articles

- Re-use any of the published material for personal use and teaching without further permission

For information on Institutional Fellowships contact consortiasales@bmjgroup.com

Visit casereports.bmj.com for more articles like this and to become a Fellow 